\title{
A Review of Research on The Teaching and Learning of Database Course Problems
}

\author{
Nuraeni Dahri ${ }^{1 *}$ \\ \{* nuraenidahri2014@gmail.com \} \\ ${ }^{1}$ Students of Doctoral Program, Technology and Vocational Education Padang, Padang State \\ University
}

\begin{abstract}
The global issue of problems in learning and teaching database subjects is a factor causing learning difficulties for students. Various problems of learning and teaching database systems lead to low learning outcomes, lack of learning motivation and lack of modeling and database design skills by students. In addition to teaching errors in managing learning, the models and approaches used in teaching and learning are not appropriate because they are not in accordance with the characteristics of the subjects and characteristics of students. The solution to the problem of learning and teaching database systems from previous researchers is to collaborate learning models based on the relevance between learning models with the characteristics of database subjects and characteristics of students so that database competencies can be fulfilled so that graduates can compete in the work industry.
\end{abstract}

Keywords: Database systems, database problems, learning and teaching.

\section{Introduction}

Database application is one of the important factors of all information systems [1]. The main purpose of studying database applications is to prepare learners to use applications as a tool to gather information and to solve business problems [2]

The database is a course that is published in the curriculum of vocational high schools, colleges of informatics and engineering education [3][4]. In general, learning competencies and teaching database systems are teaching participants can have competence as database administrators who are able to design and resolve database system problems in an organization.

\section{Methodology}

An in-depth study of learning and teaching the subject of the database system was conducted to obtain real world facts problems in learning the subject. This study also identifies the difficulties of the instructors in achieving learning competencies, as well as the difficulties of students in learning the database which results in low learning outcomes. This study also highlights aspects of concepts, strategies and perspectives of previous researchers in overcoming research problems. The author hopes that this in-depth study can give birth to a new perspective for writers to conduct research on the development of effective and adaptable 
learning models in their implementation to address the problem of teaching and learning processes (PBM) in database systems, both at the vocational high school level college level.

In database learning, some previous researchers suggested that in general, the design of learning in computer science especially in database programming is quite difficult [3]; [4]; [5]. Technical knowledge of learners is very lacking in developing database information technology that is in accordance with system requirements. Learners find it difficult to interpret the problem of existing case studies. Students have difficulty understanding the concepts and techniques of database modeling for a complex real-world case study (Mukhlisulfatih Latief, 2010). Learning that is held conventionally and PBM that is centered on teachers / lecturers has an impact on the monotonous and boring learning atmosphere for students is a factor that causes low learning outcomes.

management of learning, such as the introduction of database concepts, where students are first introduced to the knowledge of database worksheets (spreadsheet ms.excell) and then database management using database application (ms.access) [6]. Database PBM is difficult to achieve learning competencies, because there are certain parts / material that are difficult to understand and are controlled by students in general, such as difficulties in memorizing and implementing SQL (Structured Query Language) [7]. The learners have difficulty doing conceptual data modeling procedures, especially material dependency between entities, key usage, arrangement of relations between files in normalization techniques and Entity Relationship Diagram (ERD).

lack of student skills in analyzing, designing and implementing databases to solve complex abstract problems relating to the problem of organizing data in each institution or company. This has an impact on the lack of industry confidence in recruiting graduates to be placed as modern information system analysts and designers [3][4] [2]. The high level of competency in the labor market in the global era forces especially the departments of informatics to produce graduates who can compete in the world of work. The conventional learning methods and teaching of database systems are no longer effectively applied specifically to the abstract domain and database design in complex cases [8][7].

The results of the study which suggested the location of teaching and learning problems in database education as an indication of the causes of learners experiencing learning difficulties and low learning outcomes, are presented in the following scheme:

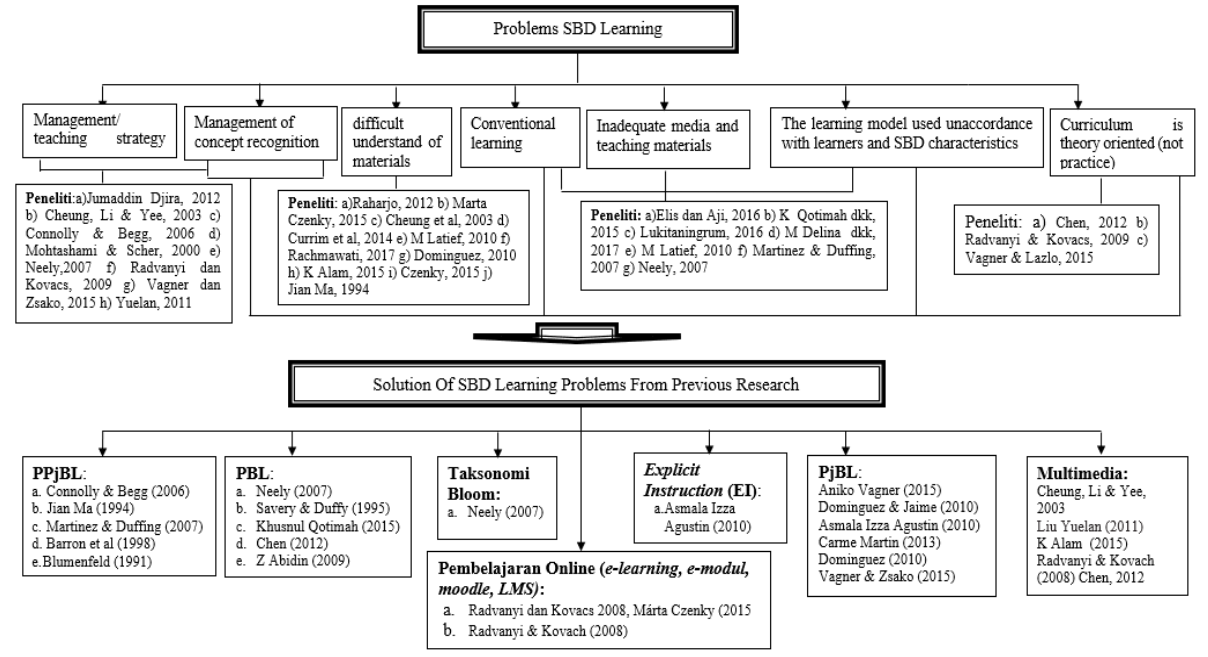

Fig. 1. experiencing learning difficulties and low learning outcomes 


\section{Result and Discussion}

Some previous researchers suggested that the problem-based learning and project-based learning model is effective and appropriate to be applied to the database system subject. Problem Based Learning (PBL) models can improve problem solving skills, improve learning outcomes, overcome student learning saturation (Khusnul Qotimah dkk, 2015; Didih Aditiyawarman, 2016; Asmala I Agustin, 2010). In terms of achieving competency in the ability to analyze and solve problems, some previous researchers applied learning that made the problem a basis of learning in improving problem solving skills for real problems in institutions or organizations [3][7] [2].

The Project Based Learning (PJBL) learning model can improve skills in designing a database system model, results and motivation to learn [9][10]. Some models and teaching and learning approaches that are effectively applied to database learning are constructivist approaches [4][7], taxonomy bloom approach [5]; JigSaw learning method, collaborative learning method [1], "Learning By Doing" concept [6], Inquiry learning model. [8] collaborating problem-based learning methods and projects for database subjects at three European universities.

Database competencies include [1][11][12] Knowledge of the characteristics, goals and structure of a relational database. 2) Capacity to properly define, create, use and manage relational databases. 3) Capacity to evaluate alternative implementations in the relational database regarding several quality criteria. 4) Knowledge of the basic aspects of data storage legislation, and security aspects related to the implementation of these regulations. 5) Knowledge of reliability[13] issues related to the use of relational databases and existing mechanisms to help avoid them. These competencies are in accordance with the characteristics of Database subjects in the form of procedural and declarative knowledge and are applicable according to real conditions so that the match is taught by applying a combination of two learning models, namely Explicit Instruction (EI) with Project Based Learning (PjBL), (Asmala Izza, 2010).

[2][14] explains the database has characteristics in the form of design procedures that support the problem solving process. [7][15] that the art of database design is difficult to learn. Constructivist approaches must be used, and project-based approaches alone are not enough because the skills needed by students are skills in modeling the reality of an organization from various fields of scienceThe database is related to information technology both in terms of material content and technological devices used to support learning. The link between technology[16] and project-based learning[17] is that learners learn how to use information and communication technology devices in real contexts. The technology integrated into the PjBL builds learning skills using information technology while learning what information and communication technology is Phyllis C. Blumenfeld (1991) suggests, "despite considerable potential, project-based education is not without problem", In order to achieve the overall learning objectives of the PBL, real problems are needed that involve students actively solving real problems to build real solutions. The Project Based Learning approach has been widely used by lecturers in the western world, because this approach is quite useful in designing effective learning. 


\section{Conclution}

An in-depth study of learning and teaching the subject of the database system was conducted to obtain real world facts problems in learning the subject. This study also identifies the difficulties of the instructors in achieving learning competencies, as well as the difficulties of students in learning the database which results in low learning outcomes. This study also highlights aspects of concepts, strategies and perspectives of previous researchers in overcoming research problems. The author hopes that this in-depth study can give birth to a new perspective for writers to conduct research on the development of effective and adaptable learning models in their implementation to address the problem of teaching and learning processes (PBM) in database systems, both at the vocational high school level college level.

\section{References}

[1] C. Martin, "Improving Learning in a Database Course using Collaborative Learning Techniques," Int. J. Eng. Educ., vol. 29, no. 4, pp. 1-12, 2013.

[2] C. Chen, "Teaching problem solving and database skills that transfer. Ball State University, Information Systems and Operations Management Department, Whitinger Business Building, 2000 W. University Avenue, Muncie, IN 47306, United States," J. Bus. Res., vol. 63, pp. 175$181,2010$.

[3] V. Fessakis, G., Dimitracopoulou, A., \& Komis, "Improving database design teaching in secondary education: action research implementation for documentation of didactic requirements and strategies," Comput. Human Behav., vol. 21, no. 2, pp. 159-194, 2005.

[4] Connolly \& Begg, "A Constructivist-Based Approach to Teaching Database Analysis and Design,” J. Inf. Syst. Educ. Spring, vol. 17, no. 1, pp. 43-53, 2006.

[5] Mohtashami \& Scher, "Aplication of Bloom's Cognitive Domain Taxonomy To Database Design, Department of Computer and Information Science," New Jersey Inst. Technol. Newark, New Jersey, 2000.

[6] L. Vagner, Aniko \& Zsako, "Negative Effects Of Learning Spreadsheet Management On Learning Database Management," Acta Didact. Napocensia, vol. 8, no. 3, 2015.

[7] M. P. Neely, "Mastery Level Learning And The Art Of Database Design," Proc. Thirteen. Am. Conf. Inf. Syst. Keystone, Color., 2007.

[8] Martinez \& Duffing, "Teaching databases in compliance with the European dimension of higher education: Best practices for better competences," Educ Inf Technol, vol. 12, pp. 211228, 2007.

[9] A. Dominguez, Cesar., \& Jaime, "Database design learning: A project-based approach organized through a course management system," Comput. Educ., vol. 55, no. 3, pp. 13121320, 2010.

[10] Jian Ma, "Problem-Based Learning With Database Systems," Comput. Educ., vol. 22, no. 3, pp. 257-263, 1994.

[11] Barron et al, 1998. Doing With ing: Lessons From Research on Problem-and Project-Based Learning, THE JOURNAL OF THE LEARNING SCIENCES, 7(3\&4), 271-311, Lawrence Erlbaum Associates, Inc.

[12] Bezerra et al, 2017. On the students' perceptions of the knowledge formation when submitted to a ProjectBased Learning environment using web applications, Computers \& Education, PII:S0360-1315(17)30220-8 DOI: 10.1016/j.compedu.2017.10.001

[13] Hmelo-Silver, Cindy E et al, 2007. Scaffolding and Achievement in Problem-Based and Inquiry Learning: A Response to Kirschner, Sweller, and Clark (2006), EDUCATIONAL PSYCHOLOGIST, 42(2), 99-10 Copyright C 2007, Lawrence Erlbaum Associates, Inc.

[14] Kovach \& Baugh, 2009. Merging Object-Oriented Programming, Database Design, Requirements Analysis, and Web Technologies in an Active Learning Environment, 
Information Systems Education Journal, ISSN: 1545-679x, Volume 7, Number 52 http://isedj.org/7/52/ June 9, 2009

[15] Rodriguez et al, 2015. Project Based Learning experiences in the space engineering education at Technical University of Madrid, Advances in Space Research, S0273-1177(15) 00483-4 http://dx.doi.org/10.1016/j.asr.2015.07.003 JASR 12336

[16] Rooij, 2009. Scaffolding project-based learning with the project management body of knowledge (PMBOK), Computers \& Education 52 (2009) 210-219, Science Direct, doi:10.1016/j.compedu.2008.07.012

[17] Yuwono \& Syaifuddin, 2017. Pengembangan Problem Based Learning Dengan Assessment For Learning Berbantuan Smartphone Dalam Pembelajaran Matematika. Jurnal Tadris Matematika, vol 10 No.2, hal 184-202, p-ISSN: 2085-5893, e-ISSN: 2541-0458, DOI http://dx.doi.org/10.20414/betajtm.v1012.116. 